ACTA THERIOLOGICA

Vol. $28,8: 147-156,1983$

\title{
Ovarian Histology and Hormonal Activity of Roe Deer Fawns
}

\author{
Grażyna MAJGIER-BOBEK
}

\begin{abstract}
Majgier-Bobek G., 1983: Ovarian histology and hormonal activity of roe deer fawns. Acta theriol., 28, 8: 147-156 [With 2 Tables \& Plate IV-VI]

Steroid hormones level was measured and histological examinations were carried out on ovaries of 14 roe deer fawns, Capreolus capreolus (Linnaeus, 1758), in the Niepolomicka Forest area (South Poland) since October till February. Average weight of ovary was $155.4 \mathrm{mg} \pm 12.2$ (S.E.) and was positively correlated with animals age $(r=0.40)$. Numerous follicles - $68.3 \%$ atretic ones among them - were found in ovaries. No Graafian follicles and corpora lutea were found. Progesterone mean level was $2747.9 \mathrm{pg} \pm 994.3$ that of estrogens $196.5 \mathrm{pg}$ \pm 68.9 and androgens $119.3 \mathrm{pg} \pm 65.5$ per $100 \mathrm{mg}$ of ovarian tissue. Progesterone and estrogens concentration did not show essential correlation with the weight of the ovary. The level of androgens decreased as the weight of the ovary increased $(r=0.70)$. The cause why gestation did not occur in roe deer fawns of the population examined is discussed.

[Inst. Zool., Jagiellonian University, Karasia 6, 30-060 Kraków, Poland]
\end{abstract}

\section{INTRODUCTION}

The roe deer Capreolus capreolus (Linnaeus, 1758) is the only European ruminant whose reproductive cycle includes delayed implantation (Short \& Hay, 1966 ; Aitken, 1974). After the rut which usually occurs in the late July (Pielowski, 1970) the embryo develops slowly, and by mid-January consists of a blastula composed of several dozen cells. Rapid development of the embryo begins the mid-January continuing to the moment of parturition in late May (Raesfeld, 1960). According to Aitken (1976) this phase of rapid growth is associated with intensive fructose secretions from the uterine glands.

Previous work on the roe deer reproductive cycle concerned the determination of the level of hormones such as testosterone and other androgens and their influence on the development of antlers in males (Short \& Mann, 1966 ; Bramley, 1976). In females, research concerned the relationship betwen the number of corpora lutea and the number of embryos (Prior, 1966 ; Borg, 1970 ; Strandgaard, 1972). A determination of progesterone and estrogen levels suggests that corpus luteum remains hormonally active even if the female is not fertilized (Sempéré, 1977 ; Hoffmann, Barth \& Karg, 1978). 
Previous research has concentrated largely on adults. It is the aim of this paper to describe histological structure of ovary of immature females less than 8 month old, and steroid hormon secretion by some tissues of these ovaries.

\section{MATERIAL AND METHODS}

The ovaries of immature female roe deer were collected from animals between October and end of January 1978/79 in the deciduous forests of the Niepolomicka Forest near Kraków $\left(50^{\circ} 07^{\prime} \mathrm{N} ; 20^{\circ} 23^{\prime} \mathrm{E}\right)$. Immediately after shooting, the animals were eviscerated and weighted. Ovaries with reproductive tracts were removed and placed in ice-cold saline, then weighted and subjected to macroscopic observation. Immediately after that granulosa cells were collected by aspiration according to a technique described later and each ovary was divided into three equal parts for simultaneous histological and histochemical investigations and for analysis of the level of progesterone, estrogens and androgens. In order to obtain histological preparations fragments of ovaries were fixed in Bouin fluid and embedded in paraffin. Sections $6 \mu$ thick were then stained with hematoxylin and eosin.

The activity of $\Delta^{5} 3 \beta$-hydroxy steroid dehydrogenase enzyme ( $\Delta^{5} 3 \beta$-OHSD) taking part in progesterone synthesis was histochemically investigated according to Levy et al. (1959), using dehydroepiandrosterone $(D H A)$ as substrate, $N A D$ as cofactor and Nitro Blue Tetrazolium (NBT) salt as hydrogen acceptor. The histochemical reaction was carried out on a suspension of live granulosa cells collected from ovarian follicles using an intradermal syringe and the needle gauge $6 \times 24$ (Channing \& Ledwitz-Rigby, 1975). Dark blue formazan granules indicate sites of enzyme activity and the amount of granules in the cell is a measure of such activity ${ }^{1}$.

Steroid analyses were carried out in homogenates of ovarian tissue using adequate radioimmunoassays. Tissue was homogenized in $1 \mathrm{ml}$ phosphate buffer saline.

1. Estrogens were assayed in ethyl ether extracts of homogenate according to Hotchkiss et al. (1971) using the antibody raised in rabbit against oestradiol-17 $\beta$ BSA-6-oxime bovine serum albumin, diluted for the assay 1:47000. Tritiated $\left(2,4,6,7 / \mathrm{n} /-^{-3} \mathrm{H}\right)$ Oestradiol Amersham, spec. act. $104 \mathrm{Ci} / \mathrm{mmol}$ in a solution of about 20000 impulses /min per sample, was used as a tracer. Antibody crossreacted with estrone $(66 \%)$ and estradiol $(2,1 \%)$. Crossreactivity of other steroids tested was below $0.1 \%$. Coefficients of variation within and between assays were $7.5 \%$ and $8.0 \%$ respectively.

2. Progesterone was analyzed according to Abraham et al. (1971) using the antibody raised in rabbit against $11 \alpha$-hydroxyprogesterone succinyl-bovine serum albumin and was used in a dilution 1:7000. Tritiated (1, 2, 6, 7/n/H) Progesterone, Amersham, spec, act. $85 \mathrm{Ci} / \mathrm{mmol}$ in a solution of about 20000 impulses $/ \mathrm{min}$ per sample, was used as a tracer. Crossreactivity of pregnenolone was $5 \%$,

1 In order to rule out a nonspecific staining the method was checked using a medium without substrate. 
$20 \alpha$-hydroxyprogesterone $1.8 \%, 17 \beta$-hydroxyprogesterone $1.1 \%$, estradiol- $17 \beta 1.2 \%$ respectively. Crossreactivity of other steroids was below $0.1 \%$. Coefficients of variation within and between assays were $7.5 \%$ and $8.0 \%$ respectively.

3. Androgens were assayed according to Dufau et al. (1972) using the antibody raised in rabbit against testosterone-3-0-carboxymethyl oxime bovine serum albumin and was used in a dilution 1:75000. Tritiated testosterone $\left(1,2,6,7 / \mathrm{n} /{ }^{3} \mathrm{H}\right)$ Testosterone, Amersham, spec.act. $81 \mathrm{Ci} / \mathrm{mmol}$ in a solution about $20000 \mathrm{impulses/}$ $/$ min per sample, was used as a tracer. Crossreactivity of $5 \alpha$-androsten was $100 \%$, dihydrotestosterone $20.8 \%$, androstendione $15.7 \%$, dehydroizoandrosterone $3 \%$, androsteron $7.4 \%$. Crossreactivity of other steroids was below $0.1 \%$. Coefficients of variation within and between assays were $7.5 \%$ and $9.7 \%$ respectively. In all assays as blank samples phosphate buffer saline was used.

\section{RESULTS}

\subsection{The Morphology and Histology of the Ovary}

Macroscopic observations indicated that the ovaries in sexually immature roe deer are very small, ovally shaped and a only few of them possessed ovarian follicles which were externally visible. The mean weight of an ovary was $155.4 \pm 12.2$ and the mean body weight of an eviscerated animal was $11.2 \mathrm{~kg} \pm 0.52$. There was no correlation between body weight and ovary weight $(\mathrm{r}=-0.17)$. A decrease in body weight over winter was observed. Average weight of animals shot in November was $12.6 \mathrm{~kg}$, those shot in December $11.2 \mathrm{~kg}$, and those shot in January $10.3 \mathrm{~kg}$. Contrary to this, an increase of the weight of ovaries was seen between November and January. The weight of the ovaries showed a positive correlation with animal's age $(\mathrm{r}=0.4 ; 0.1>p>0.05)$, however on the limit of significance only (Table 1).

Cross-sections of the ovary show that it is surrounded by ovarian epithelium overlying the tunica albuginea. The connective tissue was rich collagen fibers (Plate IV, a, b) and formed thick and dense ovarian stroma. Ovarian follicles in various stages of development were found in the cortex. Primordial and primary follicles were situated on the periphery of the ovary (Plate IV, c, d), while growing and antral follicles were situated more centrally (Plate V, e, f). Numerous blood vessels were observed in the connective tissue mainly in the medullar part of the ovary (Plate IV, a, b). Their walls were very thick which may cause rapid contraction and the efficient regulation of blood supply. Many ovarian follicles were atretic (Plate $\mathrm{V}, \mathrm{g}, \mathrm{h}$ ), and in some ovaries the number of them was fairly high $(68.3 \%)$. Neither Graafian follicles nor corpora lutea were found. 
Table 1

Body and ovarian weights of 14 roe deer fawns harvested in Niepołomicka Forest during 1978/79 (number 1-12) and 1979/80. L-left ovary, R-right ovary.

\begin{tabular}{|c|c|c|c|}
\hline $\begin{array}{l}\text { Individual } \\
\text { No. of } \\
\text { animal }\end{array}$ & Ovarian wt., mg & $\begin{array}{r}\text { Body } \\
\text { wt., } \mathrm{kg}\end{array}$ & $\begin{array}{l}\text { Date of } \\
\text { shooting }\end{array}$ \\
\hline 1 & $\begin{array}{ll}\text { R } & 160.0 \\
\text { L } & 120.0\end{array}$ & 16.0 & 5.11 .1978 \\
\hline 2 & $\begin{array}{ll}\text { R } & 105.0 \\
\text { L } & 116.0\end{array}$ & 11.0 & 18.11 .1978 \\
\hline 3 & $\begin{array}{ll}\mathrm{R} & 83.0 \\
\mathrm{~L} & 83.0\end{array}$ & 11.0 & 18.11.1978 \\
\hline 4 & $\begin{array}{ll}\mathrm{R} & 130.0 \\
\mathrm{~L} & 160.0\end{array}$ & 13.0 & 9.12 .1978 \\
\hline 5 & $\begin{array}{lr}\mathrm{R} & 70.0 \\
\mathrm{~L} & 65.0\end{array}$ & 10.0 & 10.12 .1978 \\
\hline 6 & $\begin{array}{ll}\text { R } & 340.0 \\
\text { L } & 280.0\end{array}$ & 10.0 & 25.12 .1978 \\
\hline 7 & $\begin{array}{ll}\text { R } & 160.0 \\
\text { L } & 230.0\end{array}$ & 11.0 & 28.12 .1978 \\
\hline 8 & $\begin{array}{ll}\text { R } & 190.0 \\
\text { L } & 200.0\end{array}$ & 10.0 & 29.12 .1978 \\
\hline 9 & $\begin{array}{ll}\text { R } & 230.0 \\
\text { L } & 200.0\end{array}$ & 11.5 & 1.01 .1980 \\
\hline 10 & $\begin{array}{ll}\text { R } & 120.0 \\
\text { L } & 130.0\end{array}$ & 8.0 & 14.01 .1980 \\
\hline 11 & $\begin{array}{ll}\mathrm{R} & 180.0 \\
\mathrm{~L} & 190.0\end{array}$ & 9.0 & 16.011980 \\
\hline 12 & $\begin{array}{ll}\text { R } & 200.0 \\
\text { L } & 170.0\end{array}$ & 11.0 & 20.01 .1980 \\
\hline 13 & $\begin{array}{ll}\text { R } & 130.0 \\
\text { L } & 100.0\end{array}$ & 13.0 & 15.12 .1979 \\
\hline 14 & $\begin{array}{rr}\text { R } & 112.0 \\
\text { L } & 98.0\end{array}$ & 12.0 & 18.01 .1980 \\
\hline Mean \pm S.E. & $155.4 \pm 12.2$ & $11.2 \pm 0.58$ & \\
\hline
\end{tabular}

\subsection{Results of Histochemical Investigations}

Granulosa cells collected from antral follicles showed positive histochemical reaction for activity of $\Delta^{5} 3 \beta$-OHSD. Formazan granules were distinct and stained dark bule (Plate VI, k).

\subsection{The Levels of Progesterone, Estrogens and Androgens}

The mean level of progesterone was $2747.9 \mathrm{pg} \pm 994.2$ of estrogens $196.5 \mathrm{pg} \pm 68.9$ and that of androgens $119.3 \mathrm{pg} \pm 65.5$ per $100 \mathrm{mg}$ of the ovarian tissue (Table 2). The concentration of androgens in ovaries of particular individuals showed great variability while the results for progesterone and estrogens were more consistent (Table 2). No cor- 
Table 2

Average weight of ovaries and steroid hormone levels in ovaries of roe deer fawns harvested in Niepolomicka Forest during 1978/79 (numbers 2, 4, 8, 10) and 1979/80 season (numbers 13,14 ).

\begin{tabular}{|c|c|c|c|c|}
\hline \multirow{2}{*}{$\begin{array}{l}\text { Individual } \\
\text { number }\end{array}$} & \multirow{2}{*}{$\begin{array}{l}\text { Avg. ovary } \\
\text { weight, mg }\end{array}$} & Progesterone & Estrogens & Androgens \\
\hline & & \multicolumn{3}{|c|}{$\mathrm{pg} / 100 \mathrm{mg}$ ovarian tissue } \\
\hline 2 & 110.5 & 823.7 & 55.7 & - \\
\hline 4 & 145.0 & 952.7 & 112.4 & 47.6 \\
\hline 7 & 195.0 & 4291.1 & 131.1 & 20.7 \\
\hline 8 & 195.0 & 3344.1 & 83.5 & 0.0 \\
\hline 10 & 125.0 & 1952.7 & 105.5 & 0.0 \\
\hline & 115.0 & 7692.3 & 553.8 & 353.8 \\
\hline 14 & 105.0 & 178.5 & 333.3 & 293.7 \\
\hline Mean \pm S.E. & $141.5 \pm 14.7$ & $2747.9 \pm 994.3$ & $196.5 \pm 68.9$ & $119.3 \pm 65.5$ \\
\hline
\end{tabular}

relation between progesterone as well as estrogen levels and the ovary weight was observed ( $r=0.24$ and $r=-0.43$ respectively). The level of androgen decreased as the weight of the ovary increased $(r=0.70$; $p<0.05)$.

\section{DISCUSSION}

As till recently Lenker (1973) was the only author who studied morphology of the immature ovary of white-tailed deer (Odocoileus virginianus). His data coincide with the data obtained in the present study. The process of atresia was alredy observed in both primary and growing follicles by Aitken (1973). A detailed analysis of the ovaries of investigated fawns shows, that the percentage of atretic follicles is very large. Such an increased atresia is a known phenomenon before the first ovulation among laboratory mice (Jones, 1957 ; Jones \& Krohn, 1961 ; Peters, 1969 ; Jones, 1978 ; Hoffmann \& Byskov, unpubl.) and in adult white-tailed deer (Harder \& Moorhead, 1980). In human infants Himelstein-Braw et al. (1976) showed that percentage of atretic follicles increased during their growth. Contrary to this in monkey the number of large atretic follicles was smaller (Vermande-Van Eck, 1956). Perhaps for the investigated roe deer fawns the phenomenom of excessive atresia could be additionally connected with ecological conditions in which the roe deer population lived in the Niepolomicka Forest in winter 1979/80. Great snowfall made it impossible for animals to obtain food of high quality, and this resulted in low intake of digestible energy which forced them to recover this deficite from their own energy reserves stored in the body (Perzanowski, 1978). This may have caused the observed decrease in weight during the winter, and the decrease of general 
condition of animals could cause perturbations in the growth physiology and possibly effect ovarian fuction.

No corpora lutea were observed in any of the ovaries examined which is consistent with Pielowski's (1970) observations suggesting that roe deer ovulate first in August during the 14th month of life. In sheep the occurrence of development corpus luteum was observed in animals as early as 9 months old (Foster et al., 1975). Most of the observed follicles were primary, growing and antral follicles. There were no Graafian follicles present, which suggests, that premature ovulation was unlikely.

Levels of steroid hormones in peripheral blood plasma of deer were analysed both in pregnant and non-pregnant animals only (Plotka et al., 1977; Hoffmann et al., 1978; Harder \& Moorhead, 1980). Comparison of hormone levels in ovaries of investigated animals with results of other authors is impossible since as yet there are no data for fawns available. In this study only granulosa cells were tested histochemically and on the basis of positive reaction for activity of $\Delta^{5} 3 \beta-O H S D$ it can be presumed that also granulosa cells contribute to progesterone content in the ovary. Further histochemical investigation is necessary to answer which else of the ovarian tissues are responsible for the synthesis of this hormone. According to Bjersing et al. (1972) and Wheeler et al. (1975) these tissues could be theca interna and interstitial cells as well.

The decrease of androgens level could be the result of aromatization and conversion of these hormones into estrogens. Simultaneous increase of estrogens content strongly suggests that such a situation is quite possible.

In animals which were the subject of this investigation progesterone level increased from October till February while estrogens level showed irregular fluctuation. The levels of these two hormones measured in blood plasma of mature non-pregnant roe deer exhibited similar pattern (Hoffmann et al., 1978).

The fact that white-tailed and black-tailed deer fawns (Gross, 1969 ; Verme, 1969; Thomas \& Smith, 1973) as well as ewe lambs (Foster, et al., 1975) become pregnant is known. This phenomenom however does not occur in roe deer though one case of fawn's pregnancy was mentioned (Borg, 1975). May be that lack of reproduction capacity of roe deer fawns is connected by establishing their territory in the middleof May and June, thus in the period preceding immediately the occurence of rut. The females which are unable to establish their territory, and which are usually the youngest individuals, migrate looking for new areas. In this way the population is protected from overcrowding and 
in consequence the environmental conditions are such that make possible reproduction of all the remaining females. On the other hand population regulation of other deer does not depend on territory establishment, so we sometimes deal with populations which are overcrowded, and then only individuals of high body weight are able to reproduce. This should explain why only the fawns which attained body weight are able to reproduce (Mueller \& Sadleir, 1979).

During the rut roe deer fawns are only 2 month old, while the ruting season for North American deer is two months later and American deer fawns are already 5 months old at that time. So, the body weight of female fawns exerts the essential influence on their reproductive capacity. However, there are no well documented data for the roe deer fawns to show they could get pregnant during the first year of their life.

Acknowledgements : I wish to express my most sincere thanks to Professor S. Stokłosowa, for her criticism and help in the course of this work, to Dr. M. Szoltys for invaluable help by during RIAs of steroids. The generous gift of $\mathrm{E}_{2}$ and $\mathrm{P}_{4}$ antibodies by Professor B. Cook, Univ, of Glasgow, Glasgow, Scotland, and that of testosterone antibody by Dr. B. Voracova, Czechoslovak Academy of Sciences in Prague, and the WHO SSP support are greatly appreciated.

\section{REFERENCES}

1. Abraham G. E., 1971: Radioimmunoassay of plasma progesterone. J. Clin. Endocrinol., $32: 619-624$.

2. Aitken R. J., Burton J., Hawkins J., Keer-Wilson R., Short R. V. \& Steven D. H., 1973: Histological and ultrastructural changes in the blastocyst and reproductive tract of the roe deer, Capreolus capreolus, during delayed implantation. J. Reprod. Fert., 34: 481-493.

3. Aitken R. J., 1976: Uterine secretion of fructose in the roe deer. J. Reprod. Fert., $46: 439-440$.

4. Bjersing L., Hay M. F., Kann G., Moor M., Naftolin F., Scaramuzzi R. J., Short R. V. \& Vounglai E. V., 1972: Changes in gonadotrophins ovarian steroids and follicular morphology in the sheep at oestrus. J. Endocrinol., 52: 465-479.

5. Borg K., 1970: On mortality and reproduction of the roe deer in Sweden during the period 1948-1969. Viltrevy, $7: 121-146$.

6. Bramley P.S., 1970: Territorialy and reproductive behaviour of roe deer. J. Reprod. Fert., 11: 43-70.

7. Channing C.P. \& Ledwitz-Rigby F., 1975: Methods for assessing hormone mediated differentetion of ovarian cells in culture and in short term incubations. [In: S. O. Colowick \& N.O. Kaplan, "Methods in Enzymology". 39 Part D, J. B. Hardman \& B. O'Malley, eds]. Academic Press: 183-230. New York, London.

8. Dufau M. L., Catt L.J., Tsuruhara T. \& Ryan D., 1972: Radioimmunoassay of plasma testosterone. Clin. Chim. Acta., 37 : 109-116.

9. Foster D. L., Lemons J.A., Jaffe R. B. \& Niswender G. D., 1975: Sequential patterns of circulating luteinizing hormone and follicles stimulating hormone 
in female sheep from early postnatal life through the first estrous cycles. Endocrinology, 97 : 985-994.

10. Gross J.E., 1969: Optimum yield in deer and elk populations. J. Wildl. Manage, $5: 372-389$.

11. Harder J.D. \& Moorhead D. L., 1980: Development of corpora lutea and plasma progesterone levels associated with the onset of the breeding season in white-tailed deer (Odocoileus virginianus). Biol. Reprod., 22 : 185-191

12. Himelstein-Braw R., Byskov A. G., Peters H. \& Faber M., 1976: Follicular atresia in the infant human ovary. J. Reprod. Fert., 46:55-59.

13. Hoffmann B., Barth D. \& Karg H., 1978: Progesterone and estrogen levels in peripheral plasma of the pregnant and non-pregnant roe deer (Capreolus capreolus). Biol. Reprod., 19 : 931-935.

14. Hotchkiss J. \& Atkison L. E., 1971: Time course of serum estrogen and luteinizing $(\mathrm{LH})$ concentrations during menstrual cycle of rhesus monkey. Endocrinology, $89: 177-183$.

15. Jones E. C., 1957: The ageing ovary. Thesis, University of Birmingham.

16. Jones E. C. \& Krohn P. L., 1961: The relationship between age numbers of oocytes and fertility in virgin and multiparous mice. J. Endocrinol., 21: 469495.

17. Jones R.E., 1978: The vertebrate ovary. Comparative biology and evolution. Ed. R. E. Jones.

18. Lenker D. K., 1973: Gonad activity of male and female fawns of the whitetailed deer. Proc. 27th Annual Conf. Southeast. Ass. Game and Fish Commissioners, Hot. Springs, Arkansas, October 17, 1973 : 295.

19. Levy H., Denau W. \& Rubin B. L., 1959: Visualization of steroid 3 $\beta$-dehydrogenase activity in tissue of intact and hypophysectomized rats. Endocrinology, $65: 932-943$.

20. Mueller C.C. \& Sadler M. R., 1979: Age at first conception in black tailed deer. Biol. Reprod., 21 : 1099-1104.

21. Perzanowski K., 1978: The effect of winter food composition on roe deer budget. Acta theriol., $23: 451-547$.

22. Peters H., 1969: The development of the mouse ovary from birth to maturity. Acta endocrinol., 62: 99-116.

23. Pielowski Z., 1970 : Sarna. Państ. Wyd. Roln. Leśne : 1-220.

24. Plotka S., Seal U.S. Verme L. J. \& Ozoga J. J., 1977 : Reproductive steroids in the white-tailed deer (Odocoileus virginianus borealis). II. Progesterone and estrogen levels in peripheral plasma during pregnancy. Biol. Reprod., 17 : 78-83.

25. Prior R., 1966: The roe deer of Cranborne Chase - An ecological survey. Oxford Univ. Press : 1-222.

26. Reasfeld F., 1960: Das Rehwild. Verlag Paul Parey: 1-333. Hamburg and Berlin.

27. Sempéré A., 1977: Plasma progesterone levels in the roe deer Capreolus capreolus. J. Reprod. Fert., $50: 365-366$.

28. Short R. V. \& Hay M. F., 1966: Delayed implantation in the roe deer Capreolus capreolus. Symp. zool. soc. London, 11: 173-194.

29. Short R. V. \& Mann Z., 1966: The sexual cycle of a seasonally breeding mammal, the roe deer (Capreolus capreolus). J. Reprod. Fert., 12: 337-339. 
30. Strandgaard H., 1972: An investgation of corpora lutea, embryonic development, and time of birth of roe deer (Capreolus capreolus) in Denmark. Danish Rev. Game Biol., $6: 3-22$.

31. Thomas D.C. \& Smith I. D., 1973: Reproduction in a wild and black tailed deer fawns. J. Mammal., 54: 302-303.

32. Wheeler A. G., Baird I. T., Land R. B. \& Scaramuzzi R. J., 1975 : Increased secretion of progesterone from the ovary of the ewe during the preovulatory period. J. Reprod. Fert., 45: 519-522.

33. Vermande-van Eck G. J., 1956: Neo-ovogenesis in the adult monkey. Anat. Rec., 125 : 297-324.

34. Verme L. J., 1969 : Reproductive pattern of white-tailed deer related to nutritional plane. J. Wildl. Manage., $33: 881-887$.

Accepted, December 14, 1982.

\section{Grażyna MAJGIER-BOBEK}

\section{HISTOLOGIA I HORMONALNA AKTYWNOSC JAJNIKOW KOŹLĄT SARN}

\section{Streszczenie}

Dla 14 koźląt sarn odstrzelonych od października do lutego na terenie Puszczy Niepołomickiej wykonano badania histologiczne jajników, określając w nich także poziom hormonów sterydowych. Przeciętny ciężar jajnika wynosił $155.4 \mathrm{mg} \pm 12.2$ (S.E) i był skorelowany dodatnio $(r=0.40)$ z wiekiem zwierzęcia (Tabela 1). Wśród licznych pęcherzyków znalezionych w jajnikach (Plate IV, c, d, Plate V e, f, g, h) aż $68.3 \%$ było atretycznych Plate $\mathrm{V}, \mathrm{e}, \mathrm{f}, \mathrm{g}, \mathrm{h}$ ). Nie zarejestrowano pęcherzyków Graafa ani ciałek żółtych. Sredni poziom progesteronu wynosił $2747.9 \mathrm{pg} \pm 65.5$, estrogenów $196.5 \pm 68.9$, a androgenów $119.3 \pm 65.5 \mathrm{pg}$ na $100 \mathrm{mg}$ tkanki jajnika (Tabela 2). Koncentracja progesteronu i estrogenów nie wykazywała statystycznie istotnej korelacji z ciężarem jajnika $(r=0.70)$. Przedyskutowano przyczyny, z powodu których w badanej populacji nie stwierdzono ciężarnych koźląt. 


\section{EXPLANTATION OF PLATES}

Plate IV

a. The ovarian medullar part containing small arteries and numerous collagem fibers. HE, Magnif. $\times 153$.

b. Venous blood vessels, numerous collagen fibers of connective tissue. HE, Magnif. X153.

c. Fragment of the ovary of roe der fawn. Ovarian epithelium covering the ovary. Visible ovarian cortex including primordial follicles, primary follicle and numerouls collagen fibers. HE, Magnif. $\times 153$.

d. A fragment of ovarian cortex including one primary follicle and several primordial follicles. HE, Magnif. $\times 128$.

Plate V.

e.f. Two antral, atretic follicles. HE, Magnif. $\times 60$.

g. Two atretic follicles. Numerous collagen fibers of the connective tissue are shown. HE, Magnif. $\times 102$.

h. The growing follicle surrounded by several layers of granulosa cells. He, Magnif. $\times 102$.

Plate VI.

i. The oocyt surrounded by corona cells. HE, Magnif. $\times 320$.

k. Suspension of granulosa cells assyaed for $\Delta^{5} 3 \beta$-OHSD activity. Granules of formazan are visible. $\times 153$.

Nakład $890+90$ egz. Obj. ark. wyd. 13,0. Maszynopis otrzymano

13.I.1983 r. Podpisano do druku 5.V.1983 r. Druk ukończono w maju

1983 r. Papier druk. sat. k1. III 80 g. Format B5

Białostockie Zakłady Graficzne, Zam. 64/83. Cena zł 140,- 


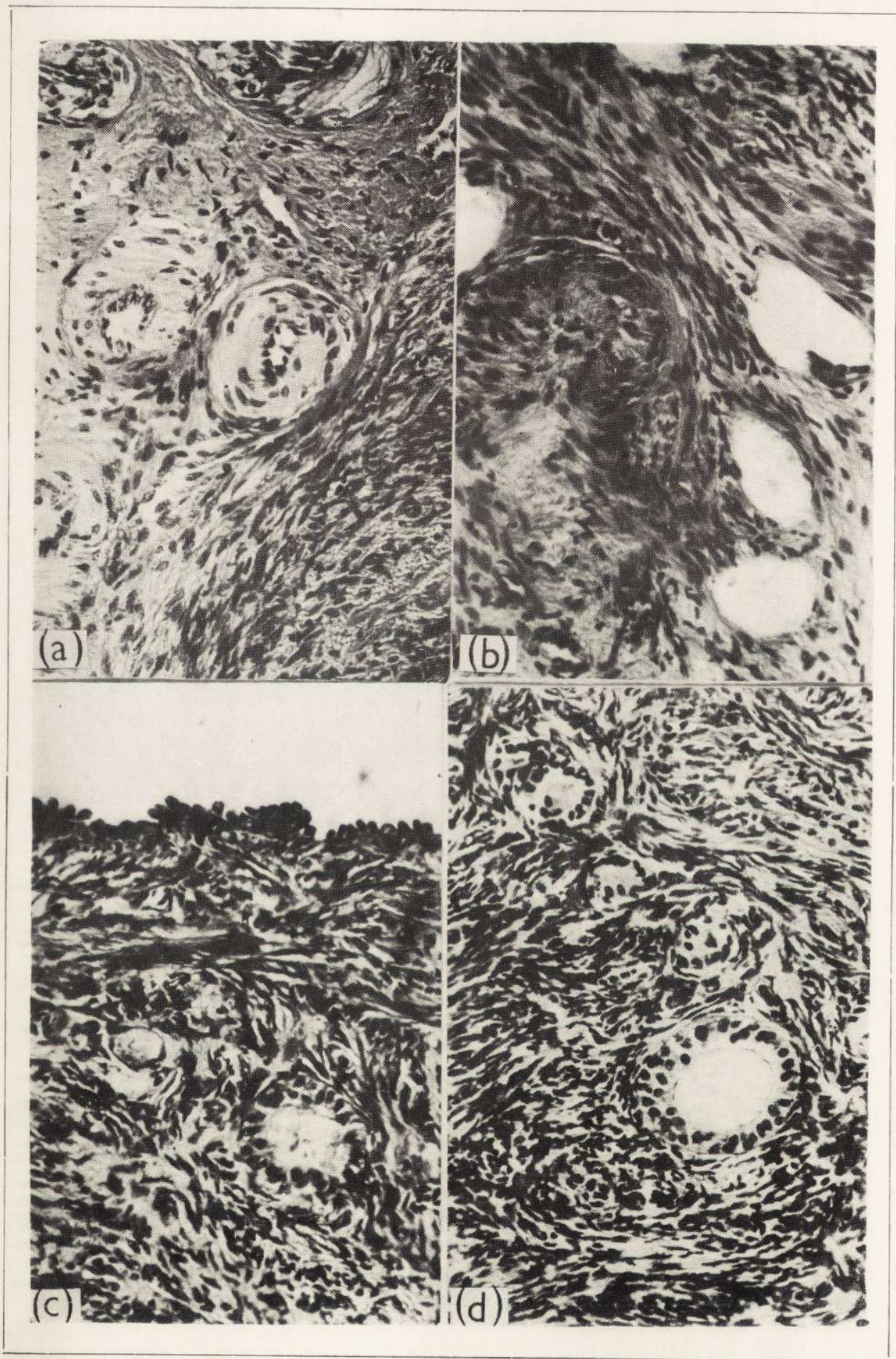

G. Majgier-Bobek

auctor phot. 


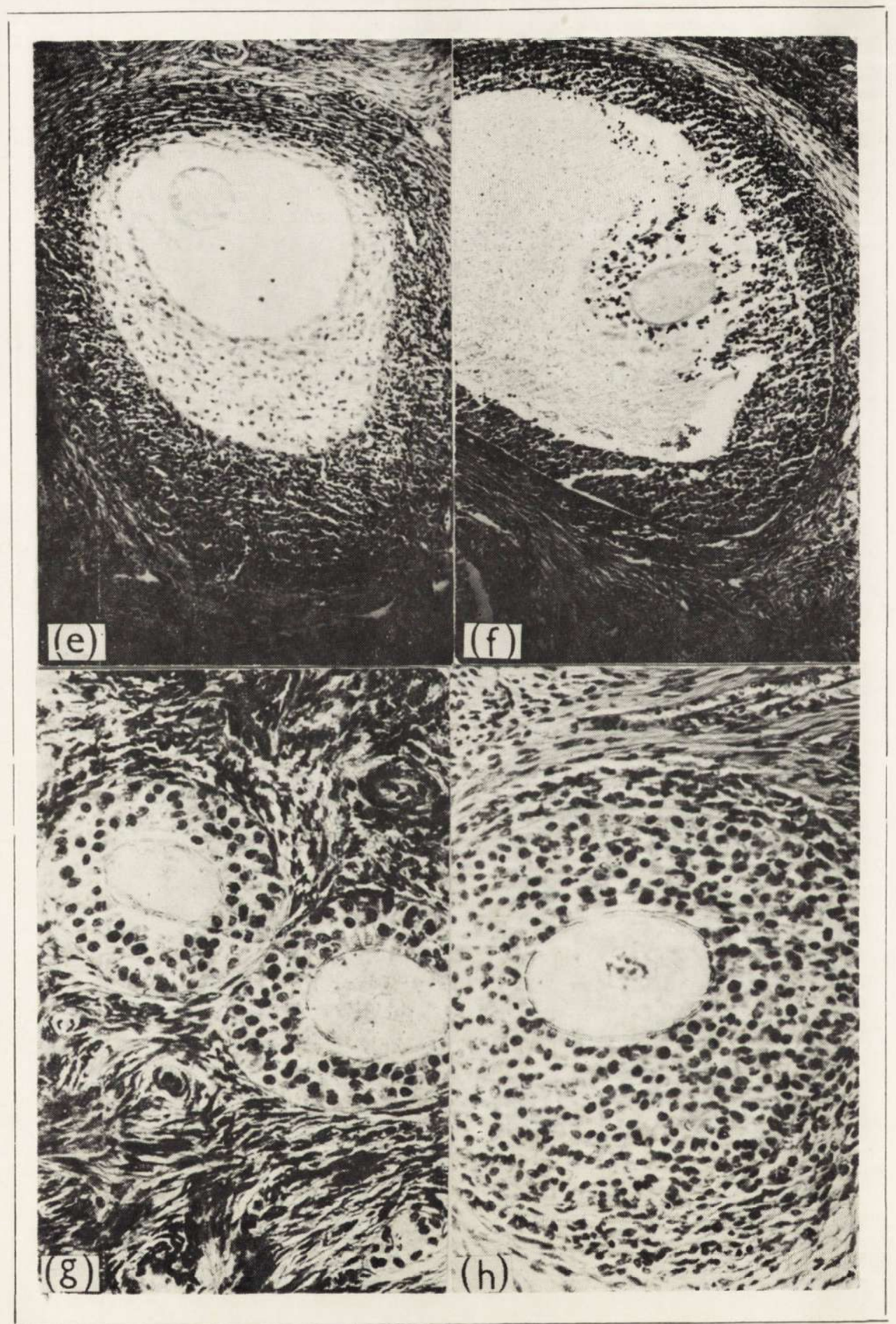

G. Majgier-Bobek 


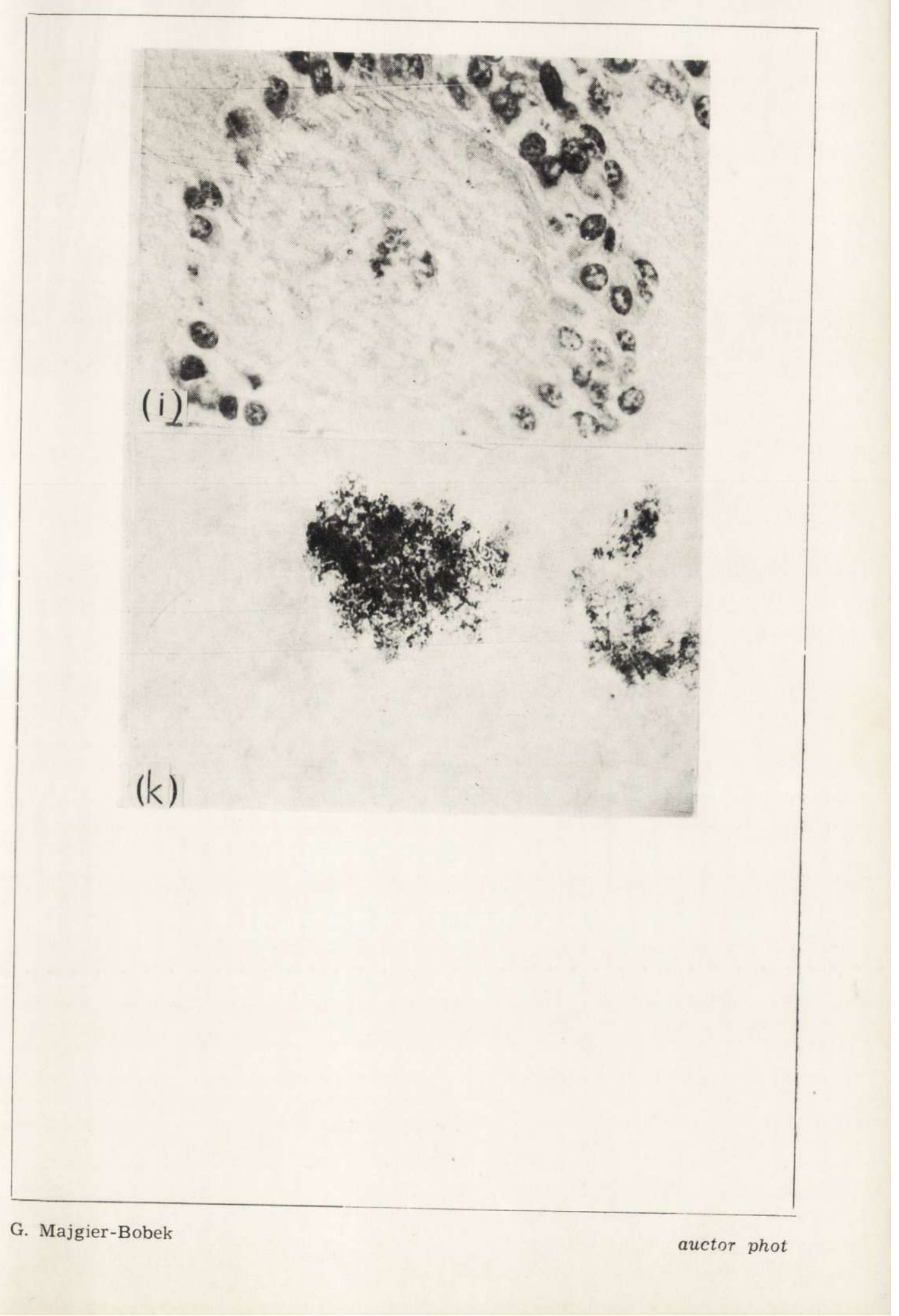

